\title{
The Impact of COVID-19 Pandemic on Education: Social Exclusion and Dropping out of School
}

\author{
Olympia Tsolou, Thomas Babalis, Konstantina Tsoli \\ Pedagogical Department of Primary Education, National \& Kapodistrian University of Athens, Athens, Greece \\ Email: olympiatsolou@gmail.com
}

How to cite this paper: Tsolou, O., Babalis, T., \& Tsoli, K. (2021). The Impact of COVID-19 Pandemic on Education: Social Exclusion and Dropping out of School. Creative Education, 12, 529-544.

https://doi.org/10.4236/ce.2021.123036

Received: February 8, 2021

Accepted: March 5, 2021

Published: March 8, 2021

Copyright $\odot 2021$ by author(s) and Scientific Research Publishing Inc. This work is licensed under the Creative Commons Attribution International License (CC BY 4.0).

http://creativecommons.org/licenses/by/4.0/

\begin{abstract}
The current study is aimed at investigating the problem of students' social exclusion and dropping out of school as a consequence of COVID-19 pandemic, which abruptly disrupted school life and education in general. The closure of all educational institutions rendered distant learning an unavoidable, yet important, measure taken by education stakeholders around the globe, which, however, raised issues of unequal participation of all students. Benefits largely remain skewed towards those who are considered privileged in all aspects, thus leaving many poor, ethnic and racial minorities, and other marginal groups shortchanged, especially in Greece, which has been tortured by a severe financial crisis since 2011. Groups of Greek students that were already experiencing adverse educational and social conditions due to their families' socio-economic status or due to specific individual and ethnic characteristics, find themselves unable to keep up with the requirements set by the mode of synchronous teaching and learning, ending up socially and educationally excluded and marginalized and ultimately being prematurely forced to abandon school, thus rising dropping-out rates tremendously. Thus, the various parameters of this multi-faceted problem are examined and social and practical recommendations are made accordingly.
\end{abstract}

\section{Keywords}

COVID-19 Pandemic, School, Social Exclusion, Dropping out

\section{Introduction}

An important historical time is being experienced by people worldwide, imposing a sudden quarantine and leaving them with no time to either realize what 
that meant or what its consequences would be. What was familiar was quickly abandoned while the need for immediate adaptation to a new way of living that of social isolation and physical distancing emerged. Complexity and uncertainty are the "new normal" and could even be for quite a period of time (Allen, Rowan, \& Singh, 2020).

COVID-19 pandemic has not only been a major health crisis but an educational one as well. The specific crisis has posed on policy makers the dilemma of either shutting down educational institutions (schools-both state and private-and universities) or keeping them open, thus either saving lives by eliminating social contacts or maintaining every state's economy. The decision that most countries worldwide have made has been to proceed with the lockdown of all educational institutions. Consequently, the physical doors of schools globally were closed and both teachers and students were abruptly forced to go into remote teaching and learning mode.

Such a decision though beneficial for the interception of each pandemic wave carries the risk of being detrimental for the smooth learning process and the overall development of students (Babalis, 2011a). The implementation of synchronous, distant learning has been adopted by the majority of the affected countries, resulting in bringing out one of the most serious problems tormenting societies for ages, that is, the problem of socially and educationally disadvantaged children. It has been proved that students coming from families with a low socio-economic status are likely to be severely affected by such conditions (Farrington, Roderick, Allensworth, Ngaoka, Keyes, Johnson, \& Beechum, 2012; Miller, 2020; Rumberger, 2011; Simba, Agak, \& Kabuka, 2016). The deprivation of appropriate technological infrastructure, the absence of Internet access, the lack of basic digital skills, or even the shortage of a quiet studying space are all constraining factors of those students' equal participation in distant learning. The financial pressure put on their families-more powerful and painful for the financially deprived families-is likely to inflict a major blow on them, resulting in their dropping out of school.

\section{Dropping out of School and Social Exclusion}

Education is a fundamental human right and the basic enabling capacity that helps human beings be free from all kinds of discrimination and domination. It is widely acknowledged that education contributes to the fullest development of human beings (Basher, 2010). As Olaniyan \& Okemakinde (2008) support, the more educated individuals, groups and nations become, the more options for development they gain. Especially, in recent years, there has been a growing interest of governments in education, which is reflected in the adoption of the principle of equal educational opportunities to all. However, many education problems are still existent with their negative repercussions on the individual, the family, the community and the educational system as a whole being more than apparent, thus constituting dropping out of school as one of the most serious of these problems. 
Dropping out of school is characterized as a long-term process of disengagement from school and school life in general, which can be traced back even in the first grades of Primary school (UNICEF, 2016). A student's decision to drop out of school is explained not only by one factor, but by a combination of convergent and divergent causes which are put forward, including individual, family, school and social parameters (Kotok, Ikoma, \& Bodovski, 2016; Houssemand \& Meyers, 2013; Arum \& Velez, 2012). The detrimental consequences of dropping out of school have been recognized for decades. Repercussions to individuals of failure to complete school include lower annual and lifetime earnings among dropouts (Tenbusch, 2016; Osgood, Foster, \& Courtney, 2010), higher unemployment rates for dropouts (Rumberger \& Lim, 2008), lower self-esteem and restricted life opportunities (Bianchi, Cavicchiolo, Lucili, Manganelli, Girelli, Chirico, \& Alivernini, 2021). Consequences for society entail dampened productivity and reduced competitiveness in the global marketplace. Structural changes occurring in the national and international economy involving shifts away from low-skill jobs in favor of high technology production and service occupations are progressively increasing the individual and social costs of dropping out. Generally speaking, there is not a unanimous consensus on a single definition of dropping out of school and, depending on the particular definition and the research method various scientists follow, different aspects of this phenomenon are revealed. The event of dropping out is arguably the educational event most likely to derail academic progress and have detrimental effects on adults' social and economic success (Rumberger, 2011; Crowder \& South, 2003).

In global literature (Frankenberg \& Kotok, 2013), the problem of dropping out of school is closely related with social exclusion. Social exclusion in education has been a widely debated issue since 1980s, when the term became popular in the western literature to explain the consequences of the radical economic, industrial and social changes that were taking place. The term reflected longterm or repeated unemployment, family instability, social isolation and the decline of neighborhood and social networks (Basher, 2010). Over time mainly two approaches have evolved in the understanding and analysis of exclusion. The dominant one is the economic approach, which is based on human capital theory and focuses on persons' unemployment that results in their inability to access social services like education, health, etc. The other one is the social approach, which focuses on the socio-political-economic conditions and processes due to which children face deprivation and equally participation in the society (Babalis, 2013). As with the case of the term "Drop-out", there is no single definition of social exclusion. Nevertheless, lack of participation in society is at the heart of nearly all definitions put forth by scholars, government bodies, nongovernmental organizations and others. For some, social exclusion is merely a new way to refer to existing concepts such as poverty or unemployment. However, a number of commentators have adopted a broader definition centered on a notion of "integration", rather than a sole concern with the distribution of resources. Thus, social exclusion is defined as a process of long-term 
non-participation in the economic, civic, and social norms that integrate and govern the society in which an individual resides (Hills, Le Grand, \& Pichaud, 2002). It is conceptually differentiated from poverty and deprivation, primarily by having a focus on the process of disengagement. In contrast to poverty and unemployment, which focus on individuals or households, social exclusion is primarily concerned with the relationship between the individual and society, and the dynamics of that relationship. In fact, in many ways, it appears useful to emphasize similarities among the debates about social exclusion and the debates about the barriers generated by any forms of disability. In the latter case, it is well recognized that some physical or mental disabilities can set a powerful barrier to the ability to interact with society and that governments have obligation to reduce or remove these barriers. In a similar vein, one can see social exclusion among non-disabled groups as socially generated barriers that reduce the ability of the excluded individuals to interact with society (Klasen, 1998). Thus, as for the disabled, those excluded as a result of other barriers and disadvantages should also enjoy the support of the state to overcome the exclusion they encounter.

Since the late 1980s, social exclusion has been used to discuss how and why poor and marginalized people fail to meet their basic rights. However, since the early 1990s, exclusion has increasingly been discussed in the discourse of global education and has become a popular term in educational discussions, focusing mainly on the issues that are responsible both globally and locally to deny children's right to education (Basher, 2010). Applying the term of social exclusion to children brings about further considerations. Since children are citizens who are entitled to rights and capabilities in their own right as these are recognized in the Convention of the Rights of the Child and national legislation governing the rights of children (UNICEF, 1989)-social exclusion is an issue violating these rights and capabilities directly. At the same time, since children grow up to be adults, and decisions, choices, and opportunities in childhood will crucially affect them as adults, the impact of their economic, social, educational, and psychological development on their status as such will have to be examined as well.

Consequently, significant discussions have evolved regarding the necessity to build an inclusive education system, so as the issue of exclusion that is based on disabilities or inequities of all forms could be addressed. Inclusive education (Hockings, 2010) means a comprehensive educational system that is designed in a way that all children enjoy equal opportunities in getting an equal quality of education. Mainstream education system fails to accommodate all children, especially those with disabilities and/or special educational needs or belong to certain racial minorities, resulting in them being excluded from the educational system and ultimately, abandoning it prematurely (Miller, 2020). Inclusive education is linked with three perspectives, that is, focusing on individuals, systems and values: "It involves reducing all forms of exclusion and increasing participation for all; the creation of systems and settings that are responsive to diversity in ways that value everyone equally and most importantly putting particular values 
into action in education and society. It is, fundamentally, a moral and political project. [...] I see inclusive values as concerned with equity, compassion and respect for diversity, human rights, participation, community, joy, honesty and sustainability" (Booth, 2009: p. 127, cited in European Agency for Special Needs and Inclusive Education, 2018).

The social exclusion of children and the role of education are of particular concern to society not only for moral reasons but because of its long-term impact on social stability and prosperity as well (Klasen, 1998). Schools have been identified as playing a critical role in reducing vulnerability to social exclusion by paving the way to productive employment and by developing students' sense of self-efficacy, self-esteem, along with their sense of belonging (Raffo \& Gunter, 2008; Hills, Le Grand, \& Pichaud, 2002). Education provides the capacity for social participation and attending school is itself an important participatory process (Klasen, 1998). Research on school practice, however, has shown that schools can also act as agents of exclusion (Booth, 2011; McCluskey, 2008). In this view, a drop-out student is regarded as a victim of social exclusion since his/her access to the social benefit of education is inhibited while, at the same time, he/she finds him/herself trapped in a vicious cycle of various kinds of exclusion and unequal participation in society in general (Razer, Friedman, \& Warshofsky, 2012). Research suggests that individuals who leave school with low levels of educational attainment are at a higher risk of experiencing social exclusion as adults, with those who lack basic literacy and numeracy skills at particular risk (Miller, 2020; Stevens, 2020; Farrington et al., 2012). Moreover, at the individual level, a diploma from upper secondary school be it from an academic or from a vocational track, makes labour market entry smoother. Likewise, dropping out of school has repeatedly been shown to dramatically increase the risk for unemployment and labour market exclusion both in the long and in the short run.

Further, the social status and the inequalities created among the families students come from, result in them also being unequal as far as their school performance is regarded (Babalis, Tsoli, Nikolopoulos, \& Maniatis, 2014). Families with low economic status have limited access to public and social benefits, including the benefit of education. Children in families of lower socioeconomic status are less likely to have supportive benefits such as a private room, a computer in the home, tutoring, or residence in a district with well-funded schools. Consequently, they are excluded both socially and educationally (Rumberger, 2011; Ratcliffe \& McKernan, 2010), which is considered to be contradictory to what democracy in education supports, that is, all socio-economic groups and ethnicities are entitled to equal access and consideration of needs and resources, so that equity is provided to all (Miller, 2020). It is of pivotal importance for schools to be democratic and student-centered, in order to promote a positive self-image for students, minimizing thus the perpetuation of social inequalities (Bradley \& Green, 2020).

Based on the aforementioned notions of fairness and equity, the devastating 
conditions that both school educators and students found themselves under through COVID-19 pandemic, are far from being supportive and indicative of a learning environment easily accessible by all, independently of their or their families' socio-economic status and the corresponding resources and benefits available. While the COVID-19 learning interruptions are unprecedented in modern times, existing research on the repercussions of missing school (due to absenteeism, regular summer breaks, and school closures) on learning can nonetheless inform projections of potential learning loss due to the pandemic (Kuhfeld, Soland, Tarasawa, Johnson, Ruzek, \& Liu, 2020). Having schools shut down, the unhampered access to education has been lost and literacy gaps have already been observed among students who belong in low socio-economic or ethnicity groups, resulting in increased dropping out rates globally (Miller, 2020).

\section{COVID-19 Pandemic and Dropping out of School}

A few months ago, an unpredictable situation COVID-19 virus pandemic reshaped the way we live, think and communicate. With coronavirus cases growing rapidly in the affected countries, we had no other option but to adjust our way of thinking and living accordingly, trying to come to terms with a new status of living. Education, of course, could not be the exception and radical changes and adaptations had to be made asap. Concerns have been raised not only by education stakeholders but also by health experts, teachers and parents while the debate about the reopening of schools has been ongoing (Murata, 2020). Teachers and parents worry about learning loss that will not easily be made up for even if schools quickly return to their prior performance levels, and health issues as education leaders are struggling to find ways of keeping the learning process going. New laws are rapidly being enforced so as distant learning is to replace the teaching and learning process in classrooms, as the social importance of schools has been recognized by all, even health experts' associations (American Academy of Pediatrics, 2020). Consequently, the political decision of closing down all educational institutions until further notice has led to growth and increased use of synchronous and asynchronous methods of teaching and learning. Students are called upon to get used to a new teaching and learning routine, being taught from the comfort of their homes and trying to get in grips with new digital tools of distant learning, such as Webex, Skype, Zoom, Messenger, etc.

However, the quality of education students receive is mainly dependent on their access to these digital learning resources, unveiling a hard reality for a great number of students and their families. The fact that only $60 \%$ of the global population are in the position to use digital tools cannot be ignored (Miller, 2020). Moreover, 20\% of girls in East Asia and the Pacific have not been able to access distance learning during COVID-19 (Babb \& Buchanan, 2020). Thus, societal issues of inequality and uninhibited access to the benefit of education have been manifested and collectively witnessed, even if these issues have been pinpointed 
in several debates on exclusion in education for years (Murata, 2020). Similarly, although levels of access to Information Technology have boomed over the past 10 years, there is considerable evidence of a so-called digital divide, namely, a growing disparity between those individuals and communities that have and those that do not have easy access to new information technologies (Selwyn, Gorard, \& Williams, 2001). Moreover, there are many more obstacles to be surpassed apart from just a student's capability of using technology. Some of these may include families that only have one internet accessible device at home and more than one child who need to use it simultaneously or even the space to offer them as a quiet learning environment or even underprivileged families that do not have such devices available to be used for e-learning. Poor housing, in particular overcrowding, access to basic amenities, and temporary accommodation are also associated with lower educational attainment (Woessmann, Freundl, Grewenig, Lergetporer, Werner, \& Zierow, 2020). The effort made at home by students to retain their learning pace given the lack of basic technological equipment to connect and participate in distant learning, the weakening of their basic learning skills due to their long absence from school and its corresponding lack of practice, the difficulties they face in trying to carry out the educational activities assigned to them remotely, but without having the appropriate help from their family environment in order to respond, the lack of supportive motivation and, ultimately, the limitation of their educational expectations due to the uncertainty that is formed in their learning environment, all comprise factors that create an explosive mixture in their effort to maintain their student identity (Saavedra, 2020).

An important parameter of the issue of the children's school exclusion due to COVID-19 pandemic and its consequent digital divide created is the children who have been experiencing social and educational exclusion for years, that is, the children with disabilities and/or special needs, of single-parent families, of various races and ethnicities as well as the Gypsy/Roma children (Calogiannakis, Karras, Ieronimakis, \& Babalis, 2018). Official statistics show that these children are over three times more likely to be excluded from school than the school population as a whole (DfE, 2018). A UK-wide literature review by Wilkin, Derrington, White, Martin, Foster, Kinder, \& Rutt (2010) supports that exclusion from school is similar to overall levels of social exclusion for these groups. It is also claimed that excluding children who belong in the aforementioned groups can actually trigger further exclusion, as one of the catalysts underpinning their exclusion is their relatively low school attendance (Graham, White, Edwards, Potter, \& Street, 2019).

The current situation of closing down schools for long periods of time and its subsequent swift to distant learning have widened the gap of inequity for these underprivileged students. Low or no attendance can affect students' ability to keep up with schoolwork and makes them more likely to fall behind academically. In other words, punishing these students by school exclusion directly increases their risk of further exclusion, due to poor attendance and falling behind 
educationally, which can aggravate a tendency for these groups to be subsequently excluded at a society level, which is already a risk (Wilkin et al., 2010). Such conditions adversely affect upon a child's health, development and access to friends and social networks, which are likely to affect school attendance and performance. According to latest study reports (Miller, 2020; OECD, 2020), approximately 1.5 billion students are out of school across 186 countries in the world in the era of COVID-19 pandemic. If students do fall behind, they have few opportunities to make up lost ground in the current education system. Such students tend to fall further behind their peers and may give up altogether the attempt to catch up (Kuhfeld et al., 2020). Moreover, the longer-term consequences of school exclusion are often profound. Research has shown that students who are excluded from school in the final two years of compulsory education are two and a half times as likely not to participate in education, training or employment between the ages of 16 and 18 than those not excluded (Dorn, Hancock, Sarakatsannis, \& Virule, 2020; Hampf, Wiederhold, \& Woessmann, 2017).

\section{Dropping out of School and COVID-19 Pandemic: The Situation in Greece}

In the spring of 2020, Greece among several other countries around the globe found itself in the center of a whirlwind, totally unprepared and blissfully unaware of the devastating consequences of such an unprecedented situation. The country's first lockdown in March and second lockdown in November, after a second coronavirus wave hit the country, has spurred an unexpected leap forward in one important area: distant learning. Under new laws passed in this period, schoolteachers were required to hold all classes online, from pre-school nurseries to university level. In this context, Greek teachers were tasked with providing distant teaching and learning, utilizing mainly their own means and at the same time trying to rise above the circumstances with dignity and effectiveness.

Greece ranks at or near the bottom of the EU class on digitization, whether you measure it by high-speed Internet connections or ownership of laptops and tablets. The government's digital-transformation "bible", a scheme to catch up with European peers by 2025, which was expected to include 400 separate projects, is months behind schedule. However, distant learning is mandatory and a new curriculum is being rolled out online, while teachers who fail to show up for an online class face disciplinary sanctions. Cisco, a telecoms-equipment company, set up a Webex platform which can provide simultaneous access for the country's 1.4 m students and 180,000 teachers (Economist, 2021). Consequently, both teachers and students were burdened with the task to keep education on track during the pandemic.

However, the factors comprising this task are many and extend on many levels. Circumstances and conditions are not ideal for all students. This new era of digital learning has left out serious parameters that were not that obvious in 
conventional classrooms and yet have profound impact on certain groups of students. Teachers have now no control over students' physical circumstances and the inequity of their situations. Some students are privileged and have a personal device at their disposal, Internet connection, fast Internet speed, a quiet area at home to attend lessons and carry out assignments, and parents available to help them stay on task and complete their school work (Stevens, 2020). Others do not. Apart from the digital divide created, students may also be disadvantaged by shortage of basic resources essential to live, chaotic housing conditions, or the responsibilities of having to look after their siblings while their parents work or even having to work due to families' poor socio-economic status (Chenge, Chenge, \& Maunganidze, 2017; Stevens, 2020). Parents' economic and educational status, family structure, their cultural and ecological profile, the relationship and the interaction among its members, their values and beliefs are some of the variables that render family environment as an agent of education and influence on a child's academic performance (Bloom \& Unterman, 2014; Farrington et al., 2012; Rumberger, 2011). Both statistical and empirical research have concluded that the children who come from better family environments do not run the risk of leaving school early as much as those coming from poorer-in all aspects-family environments (Hunt, 2008).

According to various researchers, dropping-out rates are $66 \%$ higher for underprivileged children in comparison with children showing none of the aforementioned characteristics (Babalis, Xanthacou, \& Kaila, 2018; Tenbusch, 2016). Thus, children deriving from families with low socio-economic status, living in stressful household conditions, with parents unemployed, uneducated, Roma, refugees or immigrants, are more likely to run the risk of school failure and educational and social exclusion (Stevens, 2020; Tsolou, 2020; Miller, 2020; Chenge et al., 2017; Rumberger, 2011; Rumberger \& Lim, 2008). The aforementioned parameters have become more apparent in the light of the new conditions in education that have been brought about as a result of COVID-19 pandemic. This current situation has greatly affected Greece, a country which has been tortured by a severe financial crisis with devastating consequences on all levels, including the educational one. Students coming from families with a poor socio-economic status suffered the most and their dropping-out rate increased significantly during this era of recession Greece has been experiencing. Hence, the advent of COVID-19 pandemic wreaked havoc in these students' and their families' lives and thrusted upon them with unprecedented force. The social status and the inequalities created among the families students came from, resulted in them being unequal as far as their school performance and even attendance were regarded. Consequently, they were excluded both educationally and socially.

A recent research was conducted in Greece and examined those family factors that place Greek young people at risk of leaving school early (Tsolou, 2020). A quantitative research through the use of a student questionnaire was carried out among one thousand five hundred twenty-eight (1528) students (799 boys and 729 girls) in various schools in Greece, along with a qualitative research, during 
which thirty-three (33) school principals were interviewed. It was revealed that those at most risk of dropping out of school are children from socially disadvantaged family environments and students that belong in socially vulnerable groups, such as children with special needs, children coming from families of different ethnicities and races, of refugees and Roma. More specifically, the thorough study of the aforementioned research findings brought the researcher to the conclusion that good living conditions, high family support, easy access to social benefits including the benefit of education are positively linked to the successful completion of school, findings compatible with those of several researchers (Bloom \& Unterman, 2014; Rumberger, 2011). Furthermore, according to the same research (Tsolou, 2020), as far as the students' nationality is concerned, significant differences were revealed between students that are of Greek origin and those coming from other countries, with foreign students tending to fail in school more than native ones and their dropping out rates being higher. The reasons that usually differentiate the nationally, linguistically and culturally different students are various. Namely, it is claimed that their families' cultural differentiation, socio-economic and educational background are prevailing factors of school failure and ultimately, dropping out of school (Farrington et al., 2012; Banks, 2006). Additionally, parental support and encouragement for the completion of studies is reported to be less in foreign families, a fact that was confirmed in the study (Tsolou, 2020). This could be explained by the fact that foreign students' parents are not in a position to offer their children help with their schoolwork or initiate a parent-teacher relationship so as to be constantly informed about their children's progress at school, as they are not native speakers of the language spoken and taught at schools. Finally, since there are the aforementioned barriers of culture, language, attitude and expectations on the part of foreign students, they tend to be more prone to absenteeism, truancy and juvenile delinquency-all reported as factors of dropping out of school (Bloom \& Unterman, 2014; Rumberger, 2011).

In a nutshell, the conditions which underprivileged students found themselves under due to the abrupt shutting down of schools, widens the existing educational and social gap and leaves them with no choice but abandon the synchronous mode education got into, resulting in them ultimately abandon schooling prematurely, rising thus dropping out rates in Greece extremely.

\section{Discussion}

There is neither direct evidence on how long the pandemic and its consequent lockdown are going to last nor what the long-term consequences of this situation might be on students' cognitive, educational, social and emotional development, as students' current learning process has suffered a strong decline during this unprecedented crisis, especially in schools in low socio-economic areas. Moreover, it is not possible to provide estimates of the long-run economic costs for students' families and societies in general. The former are bound to experience 
serious income losses while the latter are going to face lower economic growth, which subtracts from the overall welfare of its members (Chetty, Friedman, Hendren, \& Stepner, 2020; Hanushek \& Woessmann, 2020). The abrupt but long-lasting shutting-down of schools will likely have corresponding long-term impact on affected students' cohort. The effort to have children remain in the educational system is a matter of absolute educational priority both for their educational shield, as well as for the development of their social skills and their emotional balance. The systematic monitoring of the participation of all students in the educational process of distant education will offer the possibility of timely identification of those who decide to leave the educational system, so that immediate actions can be taken in the direction of their smooth return to it, seeking causes and reasons of this escape and advocating the most appropriate solutions.

If the goal of school is children's multifaceted and overall development, the efforts of the educational community should be intensified not only to strengthen and improve the knowledge provided, but also the socialization and emotional maturation of the child (Babalis, 2011a, 2011b; Rumberger \& Lim, 2008). In this vein, it is of pivotal importance that teachers, who are in direct daily contact with students and are asked to be informed about issues related to familial, cultural and cognitive differences among them and their special educational needs, should know the factors that contribute to early school leaving and try to eliminate them through a positive and supportive classroom (physical or virtual) climate and their daily work in general (Babalis \& Tsoli, 2017). Thus, schools should proceed with the meticulous recording of the participation of all students, monitoring the presence, behavior and progress of their learning. Efforts to maintain contact and enhance students' confidence should be continuous and in the event of potential obstacles to students' smooth participation in the process of modern distant education being identified, these should be addressed immediately the provision of the necessary equipment for participation in e-learning could be a viable solution. Personalized support should be provided to students who need it, both in terms of finding ways to enhance their learning retardation, as well as the difficulties they may encounter in managing modern technology. More attention to individualizing the instruction could elevate the learning for all students and could act to ameliorate the losses from school closure by offering learning opportunities matched to each student (Hanushek \& Woessmann, 2020).

More specifically, in Greece's educational system, with a large number of refugees and immigrant students, the disclosure of translated material to families is necessary in an effort to being mobilized and actively participate in the support of these children. In addition, the focus on the role of parents-family communication, as an important factor in enhancing the educational process from a distance, will help to prevent students' premature exit from the educational system (Babalis \& Katsaouni, 2010). It is imperative that parents be constantly and consistently provided with appropriate support material and instructions to 
support their children, especially in this difficult period of the COVID-19 pandemic. At the same time, the identification and recording of the reasons for the withdrawal of students from distant education at a national level would contribute to the timely taking of appropriate support measures to deal with, limit and hopefully eliminate the problem in case of a new school lockdown. The effort to strengthen the factors of all students' unimpeded participation in the continuation of the educational process, as it is carried out remotely, should be placed at the center of educational policy during this period. It is especially important for every child to remain in the educational process and to keep their educational expectations alive, in an effort to limit their backwardness in educational supplies and the consequent long-term impact on all aspects of their life, social and educational. At the design level of school dropout measures, identifying the population groups most at risk of dropping out of school will enable national education authorities to focus on the specific needs of these populations and design targeted and effective actions to retain and promote them within the education system, but also the return of those who have already leaked. It is widely accepted that a successful school dropout policy requires the planning and undertaking of actions aimed at specific population groups, with specific psychosocial characteristics, which are predominantly threatened with early school leaving (Kotok et al., 2016).

\section{Conclusion}

In our times, the unhindered access to the educational system is considered, more than ever, an inalienable social right and the abolition of educational exclusion at all levels of education is the beginning of every educational policy. However, unexpected, severe phenomena, as COVID-19 pandemic has been, have threatened the unimpeded school attendance by millions of students globally, widening the educational and social disparity among them, rendering the underprivileged children more at risk of abandoning school prematurely. The purpose of the present study was to put emphasis on the impact and this pandemic has on children who suffer educational and social exclusion, forcing them to drop out of the learning process as this has taken a different shape under the specific circumstances. Our hope is that this study, which sees the light of day in a difficult time for humanity, will contribute to raising the awareness of all stakeholders of all children's right to equally participate in education.

\section{Conflicts of Interest}

The authors declare no conflicts of interest regarding the publication of this paper.

\section{References}

Allen, J., Rowan, L., \& Singh, P. (2020). Teaching and Teacher Education in the Time of COVID-19. Asia-Pacific Journal of Teacher Education, 48, 233-236.

https://doi.org/10.1080/1359866X.2020.1752051 
American Academy of Pediatrics (2020). COVID-19 Planning Considerations: Guidance for School Re-Entry. New York: Aap Org.

Arum, R., \& Velez, M. (2012). Improving Learning Environments in Schools: School Discipline and Student Achievement in Comparative Perspective. Palo Alto, CA: Stanford University Press. https://doi.org/10.11126/stanford/9780804778039.001.0001

Babalis, Th. (2011a). The Socialization of the Child in the Classroom. The Role of the Teacher (2nd ed.). Athens: Diadrassi.

Babalis, Th. (2011b). Children of Single-Parent Families: Helping Their School Adjustment. Athens: Diadrassi.

Babalis, Th. (2013). Dimensions of Social Exclusion and Poverty of Single-Parent Families and Their Children in Greece. In D. Daskalakis (Ed.), The Social Sciences and the Current Crisis (pp. 459-489). Athens: Papazisi.

Babalis, Th., \& Katsaouni, K. (2010). Family-School Relationship. The Role of Parents. In F. Kalavasis, \& A. Kontakos (Eds.) Educational Planning Issues. Communication and Governance of Educational Systems (Vol. 4, pp. 148-166). Mytilene: University of the Aegean.

Babalis, Th., \& Tsoli, K. (2017). Classroom Life: Shaping the Learning Environment, Classroom Management, Strategies and Teaching Techniques. New York: Nova Publishers.

Babalis, Th., Tsoli, K., Nikolopoulos, V., \& Maniatis, P. (2014). The Effect of Divorce on School Performance and Behavior in Preschool Children in Greece: An Empirical Study of Teachers' Views. Psychology, 5, 20-26.

https://doi.org/10.4236/psych.2014.51005

Babalis, Th., Xanthacou, Y., \& Kaila, M. (Eds.) (2018). Single-Parenting in the 21st Century: Perceptions, Issues and Implications. New York: Nova Publishers.

Babb, J., \& Buchanan, N. (2020). COVID-19 Leaves Millions of Girls at Risk of School Dropout in Asia-Pacific. The Debate.

https://thediplomat.com/2020/11/covid-19-leaves-millions-of-girls-at-risk-of-school-dr opout-in-asia-pacificl

Banks, J. A. (2006). Imperatives in Ethnic Minority Education. In J. A. Banks (Ed.), Race, Culture, and Education: The Selected Works of James A. Banks. New York: Routledge. https://doi.org/10.4324/9780203088586

Basher, S. (2010). Exploring the Dynamics of Exclusion in Education. Bangladesh: Friends in Village Development Bangladesh (FIVDB).

Bianchi, D., Cavicchiolo, E., Lucidi, F., Manganelli, S., Girelli, L., Chirico, A., \& Alivernini, A. (2021). School Dropout Intention and Self-Esteem in Immigrant and Native Students Living in Poverty: The Protective Role of Peer Acceptance at School. School Mental Health, in press. https://doi.org/10.1007/s12310-021-09410-4

Bloom, H. S., \& Unterman, R. (2014). Can Small High Schools of Choice Improve Educational Prospects for Disadvantaged Students? Journal of Policy Analysis and Management, 33, 290-319. https://doi.org/10.1002/pam.21748

Booth, T. (2009). Keeping the Future Alive: Maintaining Inclusive Values in Education and Society. In M. Alur, \& V. Timmons (Eds.), Inclusive Education across Cultures: Crossing Boundaries, Sharing Ideas (121-136). Los Angeles, CA: Sage.

Booth, T. (2011). The Name of the Rose: Inclusive Values into Action in Teacher Education. Prospects, 41, 303-318. https://doi.org/10.1007/s11125-011-9200-Z

Bradley, S., \& Green, C. (2020). The Economics of Education: A Comprehensive Overview (2nd ed.). London: Academic Press. 
Calogiannakis, P., Karras, G. K., Ieronimakis, J., \& Babalis, Th. (2018). Approaching Diversity in Education: The Case of Roma Pupils. In Pedagogija un skolotāju izglītība (pp. 166-184). https://doi.org/10.22364/ped.luraksti.816.12

Chenge, R. P., Chenge, E., \& Maunganidze, L. (2017). Family Factors That Contribute to School Dropout in Rushinga District in Zimbabwe. International Journal of Law, Humanities \& Social Science, 1, 87-105.

Chetty, R., Friedman, J. N., Hendren, N., \& Stepner, M. (2020). The Economic Impacts of COVID-19: Evidence from a New Public Database Built Using Private Sector Data. https://opportunityinsights.org/wp-content/uploads/2020/05/tracker paper.pdf

Crowder, K., \& South, S. J. (2003). Neighborhood Distress and School Dropout: The Variable Significance of Community Context. Social Science Research, 32, 659-698. https://doi.org/10.1016/S0049-089X(03)00035-8

DfE (2018). Permanent and Fixed Period Exclusions in England: 2016 to 2017, SFR 35/2017. London: Department for Education.

Dorn, E., Hancock, B., Sarakatsannis, J., \& Viruleg, H. (2020). COVID-19 and Student Learning in the United States: The Hurt Could Last a Lifetime. New York: McKinsey and Co.

Economist (2021). The Lockdown Has Helped Greece to Digitise. https://www.economist.com/europe/2021/01/09/the-lockdown-has-helped-greece-to-di gitise

European Agency for Special Needs and Inclusive Education (2018). Evidence of the Link Between Inclusive Education and Social Inclusion: A Review of the Literature (S. Symeonidou, Edit.). Odense, Denmark.

Farrington, C. A., Roderick, M., Allensworth, E, Ngaoka, J., Keyes, T. S., Johnson, D., \& Beechum, N. O. (2012). Teaching Adolescents to Become Learners: The Role of Noncognitive Factors in Shaping School Performance. Chicago, IL: Consortium on Chicago School Research, University of Chicago.

Frankenberg, E., \& Kotok, S. (2013). Demography and Educational Politics in the Suburban Marketplace. Peabody Journal of Education, 88, 112-126. https://doi.org/10.1080/0161956X.2013.752628

Graham, B., White, C., Edwards, A., Potter, S., \& Street, C. (2019). School Exclusion: A Literature Review on the Continued Disproportionate Exclusion of Certain Children. London: Department for Education.

Hampf, F., Wiederhold, S., \& Woessmann, L. (2017). Skills, Earnings, and Employment: Exploring Causality in the Estimation of Returns to Skills. Large-Scale Assessments in Education, 5, 1-30. https://doi.org/10.1186/s40536-017-0045-7

Hanushek, E. A., \& Woessmann, L. (2020). The Economic Impact of Learning Losses. OECD.

http://www.oecd.org/education/The-economic-impacts-of-coronavirus-covid-19-learni ng-losses.pdf

Hills, J., Le Grand, J., \& Pichaud, D. (2002). Understanding Social Exclusion. Oxford: Oxford University Press.

Hockings, C. (2010). Inclusive Learning and Teaching in Higher Education: A Synthesis of Research. York: Higher Education Academy.

Houssemand, C. L., \& Meyers, R. (2013). The Role of Parenting in Dropping Out of School: Contributions and Limits of Qualitative Research Methods. Procedia-Social and Behavioural Sciences, 89, 523-528. https://doi.org/10.1016/j.sbspro.2013.08.887

Hunt, F. (2008). Dropping out of Schools: A Cross Country Review of Literature. NUPEA, 
$7,123-134$.

Klasen, S. (1998). Social Exclusion and Children in OECD Countries: Some Conceptual Issues. Paris: OECD.

Kotok, S., Ikoma, S., \& Bodovski, K. (2016). School Climate and Dropping Out of School in the Era of Accountability. American Journal of Education, 122, 33-67. https://doi.org/10.1086/687275

Kuhfeld, M., Soland, J., Tarasawa, B., Johnson, A., Ruzek, E., \& Liu, J. (2020). Projecting the Potential Impacts of COVID-19 School Closures on Academic Achievement. Educational Researcher, 49, 549-565. https://doi.org/10.3102/0013189X20965918

McCluskey, G. (2008). Exclusion from School: What Can "Included" Pupils Tell Us? British Educational Research Journal, 34, 447-466. https://doi.org/10.1080/01411920701609331

Miller, V. (2020). 21st Century Education through the Lens of COVID-19. Independently published.

Murata, A. (2020). Reopening Better Schools: Unexpected Ways COVID-19 Can Improve Education. Chicago, IL: Global Citizenship Education Press.

OECD (2020). Global Education Innovation Initiative at Harvard and OECD Rapid Assessment of COVID-19 Education Response. Cambridge, MA: Harvard University.

Olaniyan, D. A., \& Okemakinde, T. (2008). Human Capital Theory: Implications for Educational Development. European Journal of Scientific Research, 24, 157-162.

Osgood, D. W., Foster, E. M., \& Courtney, M. E. (2010). Vulnerable Populations and the Transition to Adulthood. Future of Children, 20, 209-229. https://doi.org/10.1353/foc.0.0047

Raffo, C., \& Gunter, H. (2008). Leading Schools to Promote Social Inclusion: Developing a Conceptual Framework for Analysing Research, Policy and Practice. Journal of Education Policy, 23, 397-414. https://doi.org/10.1080/02680930801923799

Ratcliffe, C., \& McKernan, S. M. (2010). Childhood Poverty Persistence: Facts and Consequences. Washington DC: Urban Institute.

Razer, M., Friedman, V. J., \& Warshofsky, B. (2012). Schools as Agents of Social Exclusion and Inclusion. International Journal of Inclusive Education, 17, 1152-1170. https://doi.org/10.1080/13603116.2012.742145

Rumberger, R. W. (2011). Dropping Out: Why Students Drop Out of High School and What Can Be Done about It. Cambridge, MA: Harvard University Press. https://doi.org/10.4159/harvard.9780674063167

Rumberger, R. W., \& Lim, S. A. (2008). Why Students Drop Out of School: A Review of 25 Years of Research. Santa Barbara, CA: California Dropout Research Project.

Saavedra, J. (2020). Educational Challenges and Opportunities of the Coronavirus (COVID19) Pandemic. World Bank Blogs.

Selwyn, N., Gorard, S., \& Williams, S. (2001). Digital Divide or Digital Opportunity? The Role of Technology in Overcoming Social Exclusion in U.S. Education. Educational Policy, 15, 258-277. https://doi.org/10.1177/0895904801015002002

Simba, N. O., Agak, J. O., \& Kabuka, E. K. (2016). Impact of Discipline on Academic Performance of Pupils in Public Primary Schools in Muhoroni Sub-County, Kenya. Journal of Education and Practice, 7, 164-173.

Stevens, G. (2020). Teaching in the Post-COVID Classroom. New York: Red Lotus Books.

Tenbusch, M. (2016). The Jonathan Effect: Helping Kids and Schools Win the Battle against Poverty. Downers Grove, IL: IVP Books. 
Tsolou, O. (2020). School Drop-Out: The Role of Individual, Social and School Factors. Outlining the Profile of the Greek Student. Doctoral Dissertation, Athens: National and Kapodistrian University of Athens.

UNICEF (1989). The Convention on the Rights of Child. New York: UNICEF.

UNICEF (2016). Monitoring Education Participation. Framework for Monitoring Children and Adolescents Who Are Out of School or at Risk of Dropping Out. New York: UNICEF.

Wilkin, A., Derrington, C., White, R., Martin, K., Foster, B., Kinder, K., \& Rutt, S. (2010). Improving the Outcomes for Gypsy, Roma and Traveller Pupils: Literature Review, DFE-RR043. London: Department for Education.

https://doi.org/10.1037/e607172011-001

Woessmann, L., Freundl, V., Grewenig, E., Lergetporer, P., Werner, K., \& Zierow, L. (2020). Bildung in der Coronakrise: Wie haben die Schulkinder die Zeit der Schulschließungen verbracht, und welche Bildungsmaßnahmen befürworten die Deutschen? [Education in the Corona Crisis: How Did the Schoolchildren Spend the Time the Schools Were Closed and Which Educational Measures Do the Germans Advocate?]. Ifo Schnelldienst, 73, 43-72. 